\title{
KONUŞMA EĞİTiMI
}

\author{
Prof. Dr. Nevin SELEN \\ (Ankara Üniversitesi)
}

Kişinin yaşamında, yemek içmek, yürümek kadar doğal eylemlerden biri olan "konuşma"nın etkin, düzgün ve anlamlı olabilmesi için üç eğitim yolu vardır:

1. Nefes ve ses eğitimi

2. Telâffuz eğitimi

3. Entonasyon eğitimi

\section{Nefes ve ses eğitimi:}

Nefes, konuşmayı oluşturan sesleri çıkarmak için gerekli enerji kaynağıdır. Doğumdan ölenedek alıp verdiğimiz nefesi, söylenen tümcenin gereğine göre adeta "dizginlemek" bir anlam öbeğini bir nefes verişte söyledikten sonra, ikinci anlam öbeğine geçerken nefes almak nefes eğitimine özgü alıştırmalarla mümkündür; böyle bir eğitim, konuşma eğitimi için atılan ilk adımđ̊r. Nefesi ağızdan değil burundan almak konuşmada çok önemlidir. Konuşmanın ham maddesi, enerji kaynağı olan nefes, titreşim yaparak sesi meydana getirir. Sesin ahengi, tonu, dinleyiciyi etkileyen en önemli faktördür. Bu nedenle, gereğinden çok yüksek ses, kısık ses, boğuk ses ya da cırtlak ses, patalojik bir durum söz konusu olmadığı takdirde eğitim yoluyla kısmen normale yakın hale getirilebilir. Aksi halde bu saydığımız ses kusurları dinleyicinin kulağını tırmalar. Antik düşünürlerden Quintilian'ın dediği gibi "kulağı tırmalıyan ruhu da etkilemez."

\section{Telaffuz eğitimi:}

Konuşulan dilin ses sistemini, dildeki sözcükleri olușturan seslerin niceljk ve niteliklerini öğrenmek için bir eğitimden geçmek, başka deyişle, söz konusu dilin fonetiğini öğrenmek konuşmayı daha net 
daha açık seçik ve daha güzel hale koyacaktır. Bundan başka "konuşma aksaklıkları" adı altında toplıyabileceğimiz " $r$ " seslerini telâffuz edememe "î1s fis" konușma v.b. gibi aksaklıklar da bir eğitimle düzeltilebilir. Ancak patolojik bir hal olan kekeme ya da pepeme, bu aksaklıklar arasında düzeltilmesi zor olanlardır.

\section{Entonasyon:}

Yazı dilinde, verici, mesajın kastini açık seçik iletebilmek için noktalama işaretlerine, konuşma dilinde ise "vurgu, vokal kavşağı, tümce içinde sözcükler arasındaki kısa duraklamalar, yani sezür" (Zaesur) retorik ulama, retorik çözüm, retorik sorular ve entonasyon", gibi, Prag Lengüstik ekolünün "prosodik araçlar" Amerikan Ekolünün "parçalar üstü fonemler" diye adlandırdığı araçlara başvurur. Bir sözcüğün heceleri üzerinde farklı soluk baskısı demek olan "vurgu" iki türdür. Birinci türü "anlam1 değiştiren" (distinktiv), ikincisi, söz konusu bir dil sisteminin içerdiği, benimsediği anlam ayırt etme gücünde olmayan (emphatik) vurgudur. Örnek: yazdı, yazdl okul okul, ${ }^{1}$ Vokal kavşağı için örnekler ${ }^{2}$ : ilk bahar at yarışları. Sezür için örnek, ${ }^{3}$ Rus, Amerikal1, Yahudi, Alman. Prosodik araçlardan en önemlisi Entonasyon olup üç türe ayrilır:

Terminal Entonasyon; Verilen mesajın bittiğini, sona erdiğini bildirmekle görevli olup, bu amaçla tonemin, mesaj sonunda düşmesiyle özellik kazanan entonasyon.

Pogredint Entonasyon: Bu tip entonasyonda, verici, alıcisina "mesajım daha bitmedi arkası geliyor" demek ister gibi, tonemi, tümce sonunda hafif yükseltir.

Interrogatif Entonasyon: Soru tümcelerinde kullanılan Entonasyon olup, bazı soru tümcelerinde, verinin tamamlanmasını bekler biçimde tonem tümce sonunda yine hafif yükselir.

Progredint Entonasyon, dilde, mesajın daha bitmediğini bildirme görevi ile yüklüdür. Alıcıya der ki: "mesajım daha bitmedi arkası

1 Birinci örnekte vurgu aktarımı anlan farkı yartığı için (distinktir), ikinci örnekte anlamđa hiçbir fark yapmadığından (emphatik)tir.

2 Verilen örnekte, eğer "at" sözcüğū küçük bir ara vermeden sonra pekin olarak oturtulmaz da "har" hecesi ile birleştirilir, yani birbirine ulanırsa "ilk baharat yarışları" gibi mesajın kasti saptırılır.

${ }^{3} \mathrm{Bu}$ mesajda her bir öbeğin arasında kısa duraklama (Zesur) yapılmadığı takdirde Rus asıllı Amerika 1, Yahudi asıllı Alman ya da başka biçimde anlaşıllı. 
geliyor." Bu amaçla da, tonem tümcenin sonunda melodi doruğundan. sonra aynı düzeyde yüksek kalır ya da ondan bir iki perde daha yükselir. Soru entonasyonunda, verici, alıcidan her hangi bir hususta, kendisine bilgi vermesini ister. Bu entonasyon da mesaj cevaplandırma görevi ile yükümlü bir tonlamadır.

\section{Biten sona eren entonasyon:}

Her tümcede, alıcınin dikkati çekilmek istenen en az bir sözcük vardır. Vericinin, verdiği mesajda bu sözcük anlamca en önemli sözcük onun dışında kalanlar ise, tümcenin kasti açısından daha az önemli ya da sedece biçim ve ahenk veren sözcüklerdir. Verilen mesajın kast bakımından anlamca en önemli sözcük tümcenin melodi doruğunu, daha az önemli ya da sadece biçim verme niteliğinde olanlar ise melodi doruğunun öncüleri ve artçılarıdır. Böyle yalın bildiri tümcelerinin entonasyonu orta-yüksek-alçak tondadır. Bu tümceler alt sınıflara ayrılır: I - Ö-MD-IA geliyor, gidiyor, bildirdi, yanlıştır v.b.

I Ö-MD- $\varnothing$ : yandı, kandı, aldı, verdi, gitti, kazdı v.b.

I den çok Ö-MD- $\varnothing$ : kaçırd,, titredi, gelicek, gidicek v.b.

I Ö-MD-I den çok artçı: senden aldı, hoşlanmadım, gidemez$\operatorname{dim}$ v.b.

$\varnothing-\mathrm{MD}-1$ ya da I'den çok artçı: kazdı, hoşgeldiniz, görmedim v.b. I'den çok Ö-MD-I'den çok artçı: o hakikaten güzeldi, bunu yapamam Birden çok vurgulanan hecesi olan tümceler: Örneğin "Bir kralın güzel bir kızı vardı" gibi bir tümcede hem kral ve "kızı" sözcüklerinin her ikisi de anlam yönünden önemli olduğu için her ikisi de vurgulanır, ancak melodi doruğu sadece bir tane olur, o da tümcenin bitimine doğru, kendinden sonra anlamca önemli olmiyan hece olacaktır. Adı geçen tümcede bu hece de Kızı sözcügünün "z1" hecesidir. "Kra" hecesi yan vurgu hecesi, bu iki hece arasındaki bölüm mesajın "Ritmik gövdesi”'dir, gövdenin önündekiler öncü, ard.ındakiler artçı heceler niteliğinde, biten, sona eren entonasyon türüne dahildir. Progredint (süren, mesajın devam edeceğini işaret eden) Entonasyon: Buraya kadar verdiğimiz tümcelerden daha uzun olan ve bir giriş bir de bitiş söz öbeklerinden oluşan bir tümcenin giriş öbeğinin sonunda, tonem melodi doruğundan biraz daha yüksek bir düzeyde kalırsa, alıcıda mesajın daha bitmediği izlenimi kalır, mesajın ikinci öbeğini, verici terminal entonasyonla sona erdirir. Bu tip bir tonem çalımına "progredint" (süren) entonasyon denir. Bu entonasyona giren tümcelerde, 
esas fikir söylenmedikçe, vericinin kasti için en önemli sözcük vurgulanmadıkça, dolayısıyla melodi doruğu oluşmadıkça söz konusu tümce süren entonasyon tipine dahildir. Örneğin "hava kararınca" gibi bir tümce terminal entonasyona göre söylenirse, diyelim ki "ne zaman gelecek?" gibi bir soruya cevap olarak "hava kararınca" biçiminde tonem sonda düşer; buna karşın "hava kararınca..." biçiminde ses tonu yüksekte kalırsa, alıcı bu tümceyi verilecek olan mesajın giriș öbeği olarak algılayacak ve mesajın bitmediğini arkasının geleceğini bilecektir, ikinci öbek diyelimki "göz gözü görmez oldu" gibi terminal bir entonasyon ile bitecektir. Aynı tip melodi tipi girişik tümcelerde de vardır. Eğer bu tümceler, yani girişik tümceler, başkasının sözünü aktaran tümcenin önünde duruyor ya da sözü geçen tümcenin arasına sokulmuşsa süren entonasyon, yok eğer söz konusu tümce başkasının sözünü aktaran tümceyi izliyorsa, entonasyon yönünden tüm mesajın arţ̧ı heceleri niteliğindedir. Örneğin:

Dedi: "elbette var bir bildiğim."

"Elbette" dedi "var bir bildiğim"

"Elbette var bir bildiğim" dedi.

Hitap tümcelerinde de durum böyledir. Hitap tümceleri, mesajı oluşturan diğer tümcenin sonunda duruyorsa, terminal entonasyonda olduğu gibi mesajın artçı heceleri niteliğini kazanır. Örneğin: Bekle dostum, Sakin ol evladım, Başım ağrıyor Doktor Bey, Korkma yavrum.

Buna karşın bu tip hitap tümcecikleri, tüm mesajın başında duruyorsa mesajı olușturan tümceler her biri kendi başına terminal entonasyonla söylenir. Örneğin: Dostum, bekle, evladım, sakin ol, Dr. B. başım ağrıyor. Bundan başka ara önermeler olan tümcelerde, ara önermeler kelimenin adından da anlașılacağı üzere, esas tümcenin arasına girmiş bölümlerdir ve kendi bașlarına birer fikir öbeğidirler, bu nedenle yalın bir tümcesi gibi terminal entonasyonla söylenir, ancak ara önermelerin dişında kalan tümceler ise progredint entonasyona tabidir. Örneğin "Söz verdiği zaman -geç te olsa- mutlaka gelir", tümcesinde esas bölüm "söz verdiği zaman mutlaka gelir" öbeğidir. Bu öbek bir giriş öbeği "söz verdiği zaman" bir de bitiş öbeği "mutlaka gelir" olmak üzere ikiye ayrılır. Birinci öbek, tonemin "man" hecesinde yüksekte kalmasıyla süren "progredinet" entonasyon karakterini göstermekte ve yapılan kısa duraklamadan sonra, ikinci öbeğin "mut" hecesinde oluşan melodi doruğu ile ikinci, birinciye uyanmaktadır, araya girmiş olan "geç te olsa" parçası terminal entonasyonla söylenir. 
Bir mesajda, aynı gramer türüne dahil birđen çok sözcük zincirleme birbiri arkasına dizilmiş olabilir. Ardarda dizilmiş olan bu sözcükle konuşma eylemi sırasında sezür ile birbirinden ayrılır, zincirin son halkasınadek, tonem her sözcük sonunda, alıcıya, mesajın daha devam edeceğini iletecek biçimde yüksek düzeyde kalır, son halkasında melodi doruğunu oluşturup artçı hecelerde düşük düzeyde devam ederek mesajı bitirir. Örneğin: "Pazaretesi, salı, perșembe ve cuma günleri konuşma günleridir."

Interrogatif Entonasyona soru tümceleri girer. Bunlar da üç çeşittir :

1- Tamalayıcı soru tümcesi

2- Karar soru tümcesi

3- Çift soru tümcesi

Birinci tip soru tümcesi kim, ne, nasıl soru edadiyla başlar: Kim geliyor? Ne diyor? ikinci tip "evet" ya da "hayır" cevabinı bekler "geliyor musun" "Evet" ya da hayır; üçüncü tipte bir soru, diğer bir soruya antitez olarak oturtulmuştur: "Kahve mi içersiniz çay mı?" gibi.

Buraya kadar açıklamağa çalıştığımız, üç çeşit entonasyon biçiminden terminal entonasyon: yalın bildiri, ünlem, talep, hitap tümceleri ile ara önermeler, esas tümcelerin başında duran girişik tümcelerde; çift soru tümcelerinin ikinci bölümünde; progredint entonasyon, melodi doruğu henüz oluşturulmamış, dolayısıyla tamamlanmamış tümcelerle, çift soru tümcelerinin birinci bölümünde; interrogatif entonasyon art soru tümcelerinde, uyarı, tehdit niteliğine bürünmüsş bildiri, talep ile tamalayıcı soru ve talep tümceleri nezaket biçimine dönüştüğ̈̈ zaman kullanılır. 